\section{Third sector governance: a case study in a university support foundation}

\author{
Lucimar Antônio Cabral de Ávila \\ Federal University of Uberlandia, School of Accounting \\ Sciences Uberlandia, MG, Brazil \\ Carlos Osmar Bertero \\ Getulio Vargas Foundation, Sao Paulo School of \\ Business Administration, Sao Paulo, SP, Brazil
}

Received on

08/26/2014

Approved on

05/04/2016

\section{Responsible editor:}

Prof. Dr. André Taue Saito

Evaluation process:

Double Blind Review

\begin{abstract}
Purpose - To establish a Governance Index (GOVI) to measure the relationship and influences with economic and financial performance and of volume of operations in a third sector entity.

Design/methodology/approach - Exploratory, documentary and bibliographic research and content analysis, in order to achieve a GOVI derived from the use of independence, accountability and transparency variables in the period between 1986 and 2010. Questionnaires, administrative and accounting information are all used to characterize economic and financial performance indexes and determinants of the operations volume of the studied entity. Data was statistically processed through descriptive analysis, confirmatory factor analysis, and logistic regression analysis.
\end{abstract}

Findings - The research came to two conclusions: the proposed data collection instrument presented good adjustment indexes; and the GOVI has a significant relationship with the variables used to measure performance. This may indicate that determining the GOVI is a suitable tool for confrontation and measurement of performance of nonprofit organizations. Moreover, managers' independence should be largely used in management of third sector entities.

Originality/value - The validation of the data collection instrument and the way the GOVI was obtained is one of the contributions of this study, since similar ways of measuring third sector performance were not found in literature. Choosing economic and financial performance and operations volume to study the relationship with the GOVI in nonprofit entities also was not found.

Keywords - Governance; economic and financial performance; foundation



Review of Business Management

DOI: $10.7819 /$ rbgn.v18i59.2107 


\section{Introduction}

Corporate governance has emerged in response to the need for improved relationships between managers and investors in organizations, and has triggered important discussions about its impacts and effects on security during decisionmaking processes in the capital market. As a result, certain actions began to be required for better understanding of the relationship between the various stakeholders involved in the business field, including investors, customers, suppliers, employees, and managers. The primary goal is to minimize the effects of stakeholders' different perspectives on business - the so-called agency conflicts.

In general, comparative measures between the implementation of good corporate governance practices and performance target parameters are dealt with when observing parameters inherent to for-profit companies, especially large or publicly traded companies that harbor professional administrative staff and a clear disposition towards agency conflicts. Nevertheless, much research has focused on governance in the third sector, with emphasis on collective relationships and on coping with agency problems between third sector organization managers and donors. In such cases, the use of financial measures is usually inadequate to assess the degree of organizations' success or failure, because, according to Drucker (1997), it is extremely hard to establish measures to assess their results. In social, environmental or healthcare-oriented entities, where volunteers are common, investigations are necessary concerning the measurement of results or returns as a proxy of effectiveness or efficiency, especially if they are to be compared with established governance indexes. This line of reasoning can also be applied to business institutes and foundations, since they depend on resources from sponsoring companies or partners.

In foundations established to provide specific services, institutors normally expect them to subsist, sustain themselves and grow through self-financing, with resources management being carried out as in any private organization. Management tools in any organization, public or private, should rely on resource procurement, expense reduction and control, budget projections, and use of performance measures based on economic and financial indexes and other operational measures, and to check if managers have adopted appropriate actions that are likely to assure the sustainability of the organizations. Thus, governance indexes - better adapted to their specific characteristics - emerge as a counterpoint to these organizations' economic, financial and operational performances and operations, respecting the basic parameters of the best governance practices established in Brazil, as proposed by the Brazilian Institute for Corporate Governance's (Instituto Brasileiro de Governança Corporativa, IBGC) Guide of Best Governance Practices for Business Institutes and Foundations (Guia das Melhores Práticas de Governança para Fundaçôes e Institutos Empresariais, Gife) (2009).

Drawing on IBGC's (2009) proposal for establishing governance indexes adapted to specific activities, this paper reports the case study of a foundation that supports the Federal University of Uberlândia (Universidade Federal de Uberlândia, UFU), namely Uberlândia's Educational Radio and Television Foundation (Fundação Rádio e Televisão Educativa de Uberlândia, RTU). This is a third sector organization which holds two educational broadcasting station concessions: an FM radio station and a cable and broadcast television station. It is slightly different, both in terms of support and services. Agency conflict is apparent, given UFU's and its leaders' interference and interventions in the management of RTU.

Building on the case study, the general objective of this paper is to establish a Governance Index (GOVI) that interfaces with economicfinancial performance and volume of operations in a third sector organization.

The research question is the following: does the governance model influence financial 
performance and the volume of operations in a third sector foundation?

To the best of the authors' knowledge, no studies have related governance indexes with performance in the third sector. Therefore, the results are expected to add to the existing theory.

\section{Theoretical framework}

\section{I Corporate governance and agency problems}

Corporate governance became increasingly important following numerous corporate fraud scandals that led to the loss of billions of dollars by shareholders, to countless bankruptcies, to the destruction of thousands of jobs and to a great number of criminal cases (Bergamini, 2002; Monks \& Minow, 2004). The authors consider that there were so many frauds that this overshadowed many small corporate scandals, mainly around the beginning of the $21^{\text {st }}$ century. As an example of the beginning of concern referring to the improvement of corporate governance levels, Carlsson (2001) presented an episode involving Texaco in 1984 which caused losses to shareholders at the expense of managers' interests.

Silveira (2002) describes the formalization process of corporate governance systems' organization worldwide. It began in 1985, in the USA, with the establishment of the Council of Institutional Investors; with the Cadbury report, in the UK, in 1992; with changes in the German stock market, in 1997; with recommendations for corporate governance in Japan, published in 1997; and with the launch of the Vienot report in France, in 1995, and revised in 1999. Regarding Brazil, the author highlights the establishment of IBGC, in 1995, as well as the launch of the best corporate governance practices code, that same year. The fourth version of this code was released in 2009, and, according to Marinelli (2005), the Cadbury report was revised in 1995.
The increased influence level of corporate governance is related, to a large extent, to agency conflicts. Interests can become conflicting when a part (major) depends on the decisions of another (agent), even though it is clear that the agent should make decisions that aim to benefit the major (Almeida, 2002; Arruda, Madruga, \& Freitas, 2008; Band, 1992; Carvalho, 2002). According to Jensen and Meckling (1976), individuals are inherently prone to carry out activities or make decisions that are biased towards their own preferences or desires. This, in turn, besides generating differences between managers, shareholders or majors, may lead to costs resulting, among other things, from following decision makers' actions. These claims are supported by Fama and Jensen (1983) and further corroborated by Eisenhardt (1989), who addresses four questions about the theory: definition, contribution, empirical validity and productivity of contexts for organizational researchers.

Berle (1968) had already shown concerns about the relationship between ownership and control, when tracing the profile of the American economic system. Berle and Means (1988), in an updated version of The modern corporation and private property, also express the clear divergence of interest between ownership and control. They set three functions derived from companies' issues, as follows: "to have interests in a company, to have power over it, and to act in it" (p. 123).

Ross (1973) draws attention to certain factors that can be derived from conflicts of interest, such as moral hazard and distortions in information quality. Such conflicts tend to be more forceful in moments of decision involving great uncertainty, when differences of opinion or interest tend to be more pronounced. This, in turn, calls for closer relationships and mechanisms to increase the majors' control over the agents' actions, also in the form of remuneration or establishment of incentive arrangements. 
To Noreen (1988), the Agency Theory may be used to explain detrimental ramifications arising from opportunistic behavior and lack of ethical restriction. Opportunism comes along with costs derived from mutual distrust, which requires the parties to maintain mechanisms to monitor the agents' actions. Religion, genetics and teaching techniques are somehow related to improvement in levels of ethical conduct, notably because of their punitive effect, which contrasts with deviations of conduct in the market, where punishment is unlikely.

Drawing from studies on agency theory, which address, to a large extent, the existing conflicts between shareholders (major) and managers (agent), these concepts can be extrapolated to a nonprofit organization. In such organizations, conflicts are assumed to result from clashes of opinions and interests about their directions, management or investment models to apply the available resources. In this context, governance stands as a way to control the agents participating in the decision-making process and eventually to improve the organizations' performance.

\subsection{Governance in the third sector and agency conflicts}

As described by Guimarães (2008), certain third sector definitions date back to the defense of minorities, of the environment, of social struggles and of life itself, while others consider it a set of inefficient alternatives to replace the State. To Salamon (1998), the third sector is an "impressive network of autonomous private associations, not oriented towards distributing profits to shareholders or directors, but rather serving public purposes, although from outside the formal apparatus of the State" (p. 5). Salamon and Anheier (1992) discussed the structural traits that distinguish the third sector from other organizations, including their formal business formation, non-governmental nature, autonomy, lack of profit distribution, and volunteering work.
The Brazilian Institute of Geography and Statistics (Instituto Brasileiro de Geografia e Estatística, IBGE) (2004) characterizes the third sector as groups, movements or nonprofit organizations, which are important to assure "democracy, development and citizenship" (p. 9). Montaño (2002) states that the third sector "denotes a set of private organizations and initiatives aimed at the production of public goods and services" (p. 21). Ramos (2003) emphasizes the political, democratic and economic importance of the third sector and its role in the process of building a better society while also contributing to the gross domestic product (GDP), the labor market and capital investments.

Third sector organizations may be formed as associations, entities for defense of collective interests, foundations and other types of civil society organizations of public interest. Some subdivisions can be established according to their volunteering and charitable nature, as well as their developmental, environmental and civic purposes, as described in Coelho (2000). Nearly 40 years ago, McGill and Wooten (1975) already discussed directions and management models for nonprofit organizations.

Guimarães (2008) points to corporate social responsibility, which may range from improving reputation to environmental concerns, as a basis for the third sector governance, with an emphasis on the influence and interest from various groups regarding the organizations' actions and performance. Melo and Froes (1999) see social responsibility as a way of making the companies exercise their philanthropy while also making explicit the entrepreneur's benefaction.

In a typical example of agency conflicts that are not linked to the capital market, Ferreira, Garcia and Vieira (2010) report power relationship problems between doctors and hospital administrators. Conflict in hospitals may be intense, due to the allegedly greater appreciation of a certain profession over another, causing management difficulties and interfering 
with organizations' performances. Pinto and Junqueira (2009), who used a case study to discuss power relationships in a third sector network, presented another example. The authors concluded power was decentralized, favoring fragmentation in decision-making without affecting the structural integrity of the studied organization. Nevertheless, they still underline the great importance of the central core in maintaining cohesion of the actions.

Heckert and Silva (2008) assessed service quality in the third sector. They concluded there are various types of stakeholders with different roles: several interested parties, with different perceptions of the services or activities carried out by the third sector organizations. The authors consider that the results obtained from the actions taken are as important as the process of service delivery.

Mendonça and Machado (2004) tapped into agency conflicts in the third sector while assessing whether the actions of nonprofit organization managers were aligned with the donors' or founders' interests, and whether the organization still follows its initial statutory purposes. Camera (2003) discussed the performance of boards of directors in social organizations, and also highlights the great need for alignment between management and strategic goals. Pegoraro (2008) analyzed the relationships that nonprofit higher education institutions maintained with their supporters, taking as an example the University of Contestado (Universidade do Contestado, UNC), in the Brazilian states of Santa Catarina and Rio Grande do Sul. The author claims that, although little visible, these relationships bring a classic problem of agency, with conflicts of interest, and require a collective and public analysis of problems if it is to improve conditions for both parties.

Puyvelde, Caers, Du Bois e Jegers (2012) provide in-depth analyses of agency conflicts and discuss on governance in nonprofit organizations in an attempt to integrate Agency Theory with the Theory with Stakeholder and Stewardship Theory. The authors argue that studies have been based only on the agency relationship within organizations, neglecting the importance of the stakeholders in the external environment. They claim that Agency Theory in third sector organizations should be understood in greater depth towards an evolution to the Stewardship Theory, in which two analytical perspectives can be drawn: 1) to recognize the conflict between principal and agent, while assuming that the agent will seek to meet the organizations objectives; and 2) to assume that the agent's goals are narrowly aligned with those of the principal.

Considering a development in the third sector governance, Mason, Kirkbride and Bryde (2007) presented a new model of interpretation, called Social Governance. It incorporates behavioral factors or social values, such as beliefs, meanings, and historical values, into technical analysis, overcoming and supplementing Stewardship Theory. The authors believe their model is aligned with notions of citizenship, legitimacy and participation, allowing for the incorporation of informal aspects into the management of nonprofit organizations.

Eeckloo, Van Herck, Van Hulle e Vleugels (2004) evaluated the hospital management model in Belgium, where most hospitals are nonprofit organizations. The authors found a tendency to bridging the organizational management with the activities or services delivered and showed the benefits of creating management councils composed of those individuals that are close to the activities carried out in the hospital. Among several factors favoring improvement, they found greater engagement in the development of services, improvement in supervision quality and time, better distribution of responsibility levels, optimization of meetings and troubleshooting routines (in numbers). In addition, the proposed model included a new structure of councils and competences, allowing for reduced discrepancies and less conflicts in management and interests. 
Bridging the management bodies and the hospital routines eventually led to improvements in the governance process.

Despite advances in governance-related studies in the third sector, Cornforth (2011) warns that much attention has been paid to councils, ignoring factors such as forms of government, governance and complexity levels of the structures, as well as the evolution of this type of organization. The author states that third sector governance should be addressed more broadly, including the influences from both internal and external environments.

In the present case study, agency conflicts are observed through the different understandings of how the foundation should relate to the university. In the original project, the radio and television broadcast stations were devised as a means to outreach university actions to the community and beyond. However, the project says nothing about financial maintenance.

Meanwhile, with the establishment of a nonprofit foundation to be awarded the concessions, a double understanding emerged: emotional motivations gave way to concerns about the foundation's maintenance.

According to Correia and Amaral (2008), the central assumption of the agency theory is the existence of conflicts in any relationship between a principal (in this case, UFU) and an agent (RTU), with the firm desire to maximize its own benefits. While most of the university community believes the foundation exists to meet UFU's needs, the foundation managers face the challenge of surviving, especially in financial terms, to achieve its activities and legal obligations.

\subsection{Governance principles and mechanisms applied to the third sector}

Rodrigues and Malo (2006) note the importance of establishing strategies and principles to address governance in nonprofit organizations. However, they argue, in a community venture, such information should be streamlined, made public, so there is greater mobilization and more effective engagement providing more tangible support to the decision-making due to greater participation.

To Falconer (1999), the third sector lacks observations and explanations more deeply grounded on its own management techniques: having its specific demands, it cannot simply borrow traditional administration models of private or public organizations. The author complements that the poor management of the nonprofit organizations is one of the main problems in the sector. Building on O'Neill (1998), the author provides eight categories of differences between third sector organizations and other organizations, namely: Purpose/Mission; Values; Resource Procurement; Bottom Line (Results); Legal Environment; Labor Profile; Governance; and Organizational Complexity. The author believes that the priorities for improving management in the Brazilian third sector are transparency, accountability, sustainability, service quality, and the people and communication skills.

Given the wide range of activities that can be carried out in the third sector, some research has been based on case studies providing access to the events within particular organizations. Leal and Famá (2007) studied governance building on an organization that runs a cancer hospital, and concluded that most corporate governance principles and practices are applicable to the third sector, such as ethics, corporate responsibility, accountability, and transparency. Tsai and Yamamoto (2005) came to the same conclusion: certain governance principles and practices applied in the Brazilian capital market may also be employed to the third sector, such as ethics, corporate responsibility, accountability and transparency. Machado, Mizumoto and Zylbersztajn (2006) analyzed the feature, objectives and governance mechanisms of private interest associations. Building on a case study, they highlighted the difficulties of establishing evaluation indexes of results and, consequently, 
measuring the managers' efficiency. However, the authors warned that their findings cannot be compared to those of other third sector organizations because of the wide range of activities carried out by them.

Pimenta and Brazil (2009) assessed organizational skills and managers in the third sector in Itabira (in the state of Minas Gerais, Brazil). Their results reinforced the lack of professionalism in the management of third sector organizations: unprepared managers used methods that did not meet the organizations' needs and, thus, their goals and purposes.

Cruz, Quandt, Martins e Silva (2010), Silveira and Borba (2010) address the accounting measurement of indexes of good governance practices in the third sector. Silveira and Borba (2010) assessed the level of accounting evidence presented by a sample of 39 third sector organizations in 2004, 2005 and 2006. They found $67 \%$ compliance of financial statements with transparency precepts related to accountability, which showed a clear need for improvement in these statements.

To assist in the development of best conducts and guidelines for the establishment of foundations and private associations, IBGC (2009) proposed a Guide of Best Governance Practices for Business Institutes and Foundations (Gife). The guide provides a collection of actions aimed at assisting in control structuring, management optimization, accountability, transparency and compliance to legal precepts, among others. Similarly to the best practices for profit companies, the guide is built on basic third sector principles: transparency, fairness, accountability and responsibility.

Although these principles and best practices can be used by any organization, specifically those in the third sector, IBGC (2009) clearly addresses those foundations and business institutes "maintained by companies or their shareholders for direct execution of or support to public interest projects in the most diverse areas, such as education, social development, culture, environment and healthcare" (p. 17). Still, the precepts are perfectly applicable to other third sector organizations, including foundations not maintained by companies or other public or private institutions.

$$
\text { Carrion (2000) believes that the }
$$
constitution of nonprofit organizations leads to a social commitment with problems that should be handled by the State, and philanthropy, once provided on emotional grounds, has been replaced with investments, which, if successful, can bring high returns. Third sector governance is a way to assist in the search for efficiency to maximize the likelihood of success in an organization.

According to Fernandes (2002), philanthropy isolated from the business, i.e., not structured with some link to business organizations, turns into charity, embedded with affection and personal interests.

As explained in Hudson (1999), a number of management measures should be structured in order to provide efficient administration and, consequently, the development of the organization. It should include strategies, controls, accountability, and an organizationsuitable governance system.

According to Mindlin (2009), corporate foundations must be addressed as a segment different from that of a business organization or any other nonprofit organization. Therefore, respecting their specificities and resorting to specific assessment formats and governance applications will probably prove to be more efficient.

The lack of specific measures targeting the performance assessment of the third sector organizations poses some difficulties for the development of these organizations. This open an avenue to looking for improvements in the management and operationalization of their activities. The use of governance precepts emerges as a way of structuring procedures and establishing a higher level of professionalism to conduct third sector organizations. 


\section{Methodology}

This study analyzed aspects inherent to the Uberlândia's Educational Radio and Television Foundation (RTU), sponsor of an FM radio station and a cable and broadcast television station. RTU is located within UFU, in campus Santa Monica. It is a private-law entity, with its own management performed by an Executive Director, appointed by UFU's President with approval of the Ministry of Communications. Its advisors are as follows: General Assembly, Board of Trustees, Supervisory Board, and Programming and Production Board. While the Executive Director is responsible for the direct management, he reports to the Board of Trustees, a body that is in charge of complete foundation management.

The research approach was basically empirical and analytic. According to Martins (2000), "in common, these approaches share the use of notably qualitative techniques of data collection, treatment and analysis" (p. 26). They also resort to: 1) content analysis to describe and/or interpret the contents of messages and documents (Bardin, 2011); document analysis, through the collection, classification and analysis of documents; and bibliographical analysis to assess and analyze the existing theoretical contributions to the topic under scrutiny (Martins, 2000).

\section{I Hypothesis}

The relationship is always narrow between a support foundation and the federal university which it supports. In many cases, university president is also the foundation's president, which leads to a conflict of interests and a clear distortion of good governance practices.

From its conception in 1985 to 2009, RTU faced such a problem, which was solved with the total exclusion of UFU president from its direct board in 2009. RTU's history raises insightful questions about the conflicts resulting from the alternation of managers, both within
UFU and within the foundation itself. This may have resulted in significant impacts on its business model and, consequently, in its performance, herein assessed through financial and economic indexes alongside the volume of own operations and total operations, including outsourced TV and radio programs. In this context, this study investigates the hypothesis that governance is related to economic and financial performance alongside volume of operations in a third sector organization. The aim was to understand how the governance practices related to financial and economic performance as well as volume of operations throughout RTU's history.

This research seeks to contribute to studies concerning governance in third sector organizations. It may support the establishment of a governance index for the management of an organization and simultaneous comparison of its results with economic and financial measures of performance and volume of operations. To date, the literature has neglected nonprofit organizations, and this research contributes to the development of the theoretical framework about these institutions.

\subsection{Dependent variables}

The following variables were used as proxies for economic-financial performance: Return on Asset (ROA); Return on Equity (ROE); Third Party Capital Index (IPCT); and Net Margin (NM), as provided in Matarazzo (2010). These variables were individually treated as dependent variables in simple regressions that aimed at establishing relationships with governance. These indexes were obtained from the organizations' balance sheets and statements of income from 1986 to 2010.

The following variables were used as proxies for volume of operations: Hours of Own Programming (PHP) considering both created and broadcast programs, Hours of Local Programming (LHP) on air, and number of employees (Empl.) used in operations, both employees hired by the 
foundation and UFU staff. Variable volume of operations includes data only from the television station, which started operations in 1996, because the establishment and production of TV programs incur in much higher costs than those of radio programs. Similarly, to the economic and financial performance measures, the measures of volume of operations were individually considered in simple regressions aimed at establishing relationships with governance practices.

\subsection{Independent variable}

Three constructs - independence, accountability, and transparency - were selected assuming that good governance practices provide improved financial performance and greater volume of operations, and bearing in mind that it is not possible to establish a general or universal measure for cross-analysis of organizations. The constructs are adaptations of IBGC's (2009) recommendations and were used to compose a Governance Index (GOVI) for the foundation under scrutiny. The choice of constructs was based on their intense recurrence within the institution.

Specifically, independent variable GOVI was established using the average of responses obtained through a research questionnaire over each period, so as to assess whether governance practices had an impact on the economic and financial performance as well as on the volume of operations.

\subsection{Data collection}

The period of analysis ranges from 1986, year of foundation, to 2010, year immediately prior to the beginning of this study. Yet, the collection instrument was subdivided in order to coincide with complete or partial terms of UFU's presidents: 1986-1988; 1989-1992; 1993-1996; 1997-2000; 2001-2004; 2005-2008; and 20092010. This subdivision was necessary because UFU's president was RTU's Executive Director, which caused changes in the direct administration in each of these periods and, in theory, could impact on the corporate governance practices adopted by each manager.

Independent variable GOVI was built based on a closed-ended questionnaire with fifteen questions, five for each construct, in the form of statements. Answers possibilities ranged from 0 (zero) to 10 (ten), with the highest score meaning total alignment with the statement. The questions emerged from aligning the variables selected for GOVI with actions of good governance practices for the third sector after an extensive examination of the existing management occurrences at RTU. Besides, the researchers asked for the help of founders and managers who were at the head of the foundation in any of the periods evaluated.

A pre-test was applied to professors of both UFU and Getúlio Vargas Foundation's Business School in São Paulo, Brazil. The final questionnaire was hosted on Survey Monkey, a specialized website for this type of data collection. However, several respondents requested the questionnaire in printed form. A population of 336 individuals was considered for data collection, including UFU public servers and foundation staff who had provided services to or at RTU's Foundation in one or more periods for at least 90 days (maximum period of a probation contract). Following adjustments for deaths and participation refusals, the population was reduced to 266 , of which 146 provided valid responses $(54.89 \%)$.

Separately to the questionnaire, five questions were answered by the researchers based on document analysis of the foundation's statute, board of trustees' meeting minutes and other documents. The results were used to compare if average response indexes obtained through the questionnaire agreed with the one in the foundation's records. 


\subsection{Statistical procedures}

Following the establishment of the GOVI, the economic-financial performance indexes, adjusted from Matarazzo (2010), the data of the independent variables, i.e., those obtained from the questionnaire, were submitted to a descriptive analysis.

Using the Statistical Package for the Social Sciences (SPSS) and the Analysis of Moment Structures (AMOS) software, data was submitted to descriptive analysis of independent variables - that is, of variables used in the questionnaire, allowing the nature of their distribution to be visualized and, later, the descriptive analysis of dependent variables to be carried out, following their transformation into dummy variables to facilitate logistic regression. Then, Confirmatory Factor Analysis (CFA) was performed to assess the relationship of the governance variables with economic and financial performance and volumes operations. CFA built on the following: reliability and internal consistency, for Cronbach's Alpha with values above $60 \%$ (Hair, Anderson, Tatham, \& Black, 2005b; Hair, Babin, Money, \& Samouel, 2005a), to assess if constructs had been properly measured; and discriminant validity, for Chisquare statistics comparison between index pairs, to assess whether the constructs were measuring different things. CFA also assessed modification indexes to minimize the value of the Chi-square statistic in the models.

Following the CFA, the average of each construct was calculated, and its value was used in logistic regression analysis as independent variables. The model was tested and its results were analyzed.

\section{Results}

\section{I Indexes of economic and financial performance and volume of operations}

Following the economic-financial performance indexes selection, adapted from Matarazzo (2010), from assessment of the most appropriate criteria for measuring the performance of RTU Foundation, it allowed for the establishment of results for the period, grouped using averages between the years.

Similarly, after determining the programming hours generated within the network itself, as well as the hourly amount conveyed by the University TV, described separately in own and third-party programs, it was possible to verify that RTU experienced a considerable increase in local broadcasting hours, but a large oscillation in the hours of its own programs, which may indicate discontinuities referring to management changes (i.e., new ideas and disclosure standards were implemented in every change of managers).

\subsection{Descriptive analysis}

Table 1 presents the descriptive statistics of the independent variables used in the model. 
Table 1

Descriptive statistics of independent variables obtained from the study and belonging to the questionnaire

\begin{tabular}{|c|c|c|c|c|c|}
\hline Variables & $\mathbf{n}$ & Mean & Stand dev. & Minimum & Maximum \\
\hline in 1 & 146 & 3.95 & 3.47 & 0.00 & 10.00 \\
\hline in 2 & 146 & 4.06 & 3.59 & 0.00 & 10.00 \\
\hline in 3 & 146 & 4.38 & 3.58 & 0.00 & 10.00 \\
\hline in 4 & 146 & 4.33 & 3.67 & 0.00 & 10.00 \\
\hline in 5 & 146 & 4.30 & 3.95 & 0.00 & 10.00 \\
\hline ac1 & 146 & 3.53 & 3.65 & 0.00 & 10.00 \\
\hline ac2 & 146 & 3.14 & 3.73 & 0.00 & 10.00 \\
\hline ac3 & 146 & 4.34 & 3.96 & 0.00 & 10.00 \\
\hline ac4 & 146 & 2.74 & 3.34 & 0.00 & 10.00 \\
\hline ac 5 & 146 & 3.76 & 3.79 & 0.00 & 10.00 \\
\hline $\operatorname{tr} 1$ & 146 & 4.03 & 3.89 & 0.00 & 10.00 \\
\hline $\operatorname{tr} 2$ & 146 & 4.84 & 3.97 & 0.00 & 10.00 \\
\hline tr3 & 146 & 4.15 & 3.80 & 0.00 & 10.00 \\
\hline $\operatorname{tr} 4$ & 146 & 2.57 & 3.31 & 0.00 & 10.00 \\
\hline $\operatorname{tr} 5$ & 146 & 3.96 & 3.72 & 0.00 & 10.00 \\
\hline
\end{tabular}

Note. in: independence; ac: accountability; tr: transparency

The average of all responses, whether in the independence, accountability or transparency construct, does not reach $50 \%$ of the maximum score. This indicates low compliance to the standards established for good corporate governance practices.

Despite the large time lapse in data collection, an alignment is apparent between the responses obtained in the questionnaire for the three groups of variables and allows for drawing inferences about the use of principles of governance in RTU management. Cronbach's Alpha adds to this analysis, but was performed after the completion of CFA.
In addition, a verification mechanism for some items presented in the questionnaire, through documentary analysis, confirms the possibility of assessing whether the average indexes of responses obtained are consistent with the foundation's records.

The next step consisted in preparing the descriptive statistics for the dependent variables in the research model. Table 2 summarizes the data. For all three variables related to volume of operations, the total number of observations was 107 comments, because they are available only for 1997-2010. 
Table 2

Descriptive statistics for study dependent variables

\begin{tabular}{|c|c|c|c|c|c|c|}
\hline Variables & $\mathbf{n}$ & Mean & Stand. dev. & Minimum & Maximum & Median \\
\hline ROA (\%) & 146 & 0.74 & 1.94 & -0.88 & 6.49 & 0.58 \\
\hline ROE (\%) & 146 & 7.11 & 11.76 & -1.74 & 26.49 & 0.15 \\
\hline IPCT (\%) & 146 & 0.50 & 2.69 & -2.53 & 4.78 & -0.35 \\
\hline NM (\%) & 146 & 0.06 & 0.49 & -0.55 & 1.00 & 0.04 \\
\hline PHP & 107 & 101.13 & 24.87 & 63.50 & 128.25 & 115.50 \\
\hline LHP & 107 & $2,693.99$ & $1,691.48$ & 580.25 & $4,742.25$ & $2,452.13$ \\
\hline Contrib. & 107 & 64.19 & 14.64 & 48.00 & 82.00 & 62.00 \\
\hline
\end{tabular}

Note. ROA: Return on Assets; ROE: Return on Equity; IPCT: Third Party Capital Index; NM: Net Margin; PHP: Hours of Proper Programming; LHP: Hours of Local Programming; Empl: Employees.

Table 2 provides mean, standard deviation, median, minimum and maximum value for each variable. Median was used as the basis to transform the dependent variables into dummy variables for the proposed model to be assessed based on logistic regression.

Transforming all dependent variables into dummy variables allowed for estimating the parameters of the proposed regression model. However, it is necessary, first, to check whether the independent variables are properly measured.
This was performed through the analysis of the reliability and internal consistency of the questionnaire, alongside the discriminant analysis of the constructs.

\subsection{Confirmatory factor analysis (CFA)}

The model parameters were estimated in SPSS AMOS software, based on answers drawn from 146 questionnaires. Table 3 describes the adjustment indexes.

Table 3

Adjustment indexes for confirmatory factor analysis - adjusted model

\begin{tabular}{|c|c|c|c|c|c|}
\hline General Index & 1st Stage & 2nd Stage & 3rd Stage & 4th Stage & 5th Stage \\
\hline Chi-square & 517.714 & 357.490 & 291.952 & 222.093 & 90.199 \\
\hline Degrees of freedom & 87 & 74 & 62 & 51 & 24 \\
\hline Chi-square / Degrees of freedom & 5.941 & 4.831 & 4.709 & 4.355 & 3.758 \\
\hline Probability level & 0.000 & 0.000 & 0.000 & 0.000 & 0.000 \\
\hline Goodness of Fit (GFI) & 0.680 & 0.732 & 0.764 & 0.797 & 0.890 \\
\hline Adjusted goodness of fit (AGFI) & 0.558 & 0.620 & 0.654 & 0.690 & 0.793 \\
\hline \multicolumn{6}{|l|}{ Comparative Index } \\
\hline Normed fit index (NFI) & 0.776 & 0.826 & 0.845 & 0.867 & 0.924 \\
\hline Incremental fit index (IFI) & 0.806 & 0.857 & 0.874 & 0.894 & 0.943 \\
\hline Comparative fit index (CFI) & 0.805 & 0.855 & 0.873 & 0.893 & 0.942 \\
\hline Tucker-Lewis coefficient (TLI) & 0.764 & 0.822 & 0.840 & 0.862 & 0.914 \\
\hline
\end{tabular}


Adjustments were carried out to improve the model. To this end, the Modification Index was analyzed to "evaluate the fit of a specified model, which are calculated for each nonestimated relationship" (Hair et al., 2005b, p. 491). However, other factors should be considered. With the adjustments, variables TR4, PC3, IN2, TR3, IN4 and PC2 were excluded.

The remaining variables in the constructs are consistent with IBGC's (2009) prescriptions considering the present case study. However, results may be different in other non-private organizations. The adjustment indexes were the closest to those indicated in the literature.

Bartlett's Sphericity Test and KMO (Kaiser-Meyer-Olkin) Extent were applied to the new questionnaire structure to assess data adjustment to the factor analysis. The Sphericity test was significant at $1 \%$, and the KMO measure was 0.899 .

Cronbach's Alpha was used to analyze reliability and internal consistency of the data collection instrument for each of the constructs. The results were: 0.776 for independence, 0.911 for accountability, and 0.930 for transparency. Since they were all above $60 \%$, and therefore feature reliability and internal consistency, they were considered suitable for the analyses (Hair et al., 2005b, p. 90).

Despite the good adjustment indexes, discriminant validity of data collection instrument was also carried to evaluate "whether the items that reflect a factor are not correlated with other factors" (Marôco, 2010, p. 176).

Table 4

Results for discriminant analysis, by constructs pairs

\begin{tabular}{|c|c|c|c|c|c|c|}
\hline \multirow{2}{*}{ Pairs of constructs analyzed } & \multicolumn{2}{|c|}{$\begin{array}{l}\text { Without Perfect } \\
\text { Correlation }\end{array}$} & \multicolumn{2}{|c|}{$\begin{array}{l}\text { With Perfect } \\
\text { Correlation }\end{array}$} & \multicolumn{2}{|c|}{$\begin{array}{l}\text { Difference } \\
\text { (Chi-Square) }\end{array}$} \\
\hline & Chi-Square & d.f. & Chi-Square & d.f. & Difference & Signif. \\
\hline \multicolumn{7}{|l|}{ Independence (IN) } \\
\hline Accountability (AC) & 11.056 & 8 & 60.874 & 9 & 49.818 & $<0.01$ \\
\hline Transparency (TR) & 17.503 & 8 & 69.565 & 9 & 52.062 & $<0.01$ \\
\hline \multicolumn{7}{|l|}{ Accountability (AC) } \\
\hline Transparency (TR) & 55.939 & 8 & 229.796 & 9 & 173.857 & $<0.01$ \\
\hline
\end{tabular}

Note. The difference (Chi-square) indicates the Chi-square statistic subtraction from the model, with perfect correlation between the two constructs, but no perfect correlation of any of them with the model. The signif. column indicates the significance level for the difference (Chi-square), with a degree of freedom.

The results in Table 4 show that the constructs used in the study may present some correlation with each other, but they do measure different things.

\subsection{Logistic regression}

The mean of the three constructs was calculated to estimate the model and measure
GOVI. The results are summarized in Table 5, which also exhibits the signals of the relationships between the dependent variable and GOVI. 
Table 5

Results for the logistic regression analyses between GOVI and dependent variables

\begin{tabular}{cc}
\hline Variables & GOVI \\
\hline ROA & + \\
ROE & + \\
IPCT & + \\
NM & + \\
PHP & + \\
LHP & + \\
Contrib. & + \\
\hline
\end{tabular}

Note. +: indicates that the relationship between the variables was positive with significance at $5 \%$.

-: indicates that the relationship between the variables was negative with significant at $5 \%$.

n.s.: indicates that the relationship between the variables was not significant.

ROA: Return on Assets; ROE: Return on Equity; IPCT: Third Party Capital Index; NM: Net Margin; PHP: Hours of proper programming; LHP: Hours of Local programming; Empl: Employees.

As shown in Table 5, all variables showed a positive relationship with GOVI, indicating that the use of good governance practices favorably influenced RTU's economic and financial performance. This supports the alternative hypothesis, that is, there is a relationship of the governance variables with the economic and financial performance and volume of operations.

The positive relationship of GOVI with Hours of Own Programming (PHP) created and broadcast by RTU, denoting the influence of governance, is closely related to the difficulty in maintaining resources, due to the oscillation of results and absence of investments for asset modernization. This impaired the implementation of new programs produced by RTU, because the costs are high and no records were found that a RTU program had sponsorship for implementation and maintenance.

GOVI positive relationships with ROE, MN, IPCT and Hours of Local Program (LPH) show that the foundation's management has always been carried out with third-party resources, either in the form of loans from other UFU support foundations or in the form of funds raised by marketing time slots for programs produced by third parties. Either way, this always interferes with the level of Return on Equity due to change in the net margin caused by oscillations of results in each period. In addition, the positive relationship of GOVI with the number of employees (Empl.) shows that more labor is needed to meet the demands created by increased marketing of time slots, especially for live broadcasts.

Aiming to identify the variables with greater influence on the results, the analysis was performed again. However, GOVI was segregated in its three constructs. Apparently, no variable, in isolation, had a direct relationship with GOVI, which somehow contradicts the general analysis presented in Table 5.

The considerable variable oscillation over the seven periods used for this study's analysis should be considered; it may explain the non-significant behavior of the variables in each term individually. However, grouped in general evaluation, it was statistically significant, allowing us to infer that governance interfered with economic-financial performance and the volume of the Foundation's operations.

As to the volume of operations in the 1997-2010 period, the findings show a downward tendency in hours of own programs despite the growing GOVI results. This is consistent with RTU's long records of transactions related to third-party program to maintain its activities and face the high costs of creating its own programs. The results also show clearly that the growth in the number of employees follows the same behavior of the increasing hours of local programs, most notably for the use of third-party programs.

Thus, the influence of management when drawing a line of action that is focused on the inclusion of third-party programs at the expense of the foundation's own programs is clear. It is also clear that GOVI had a positive influence on the volume of operations, as shown in Table 5. 


\section{Final considerations}

This study set out to understand the influence of governance practices in a foundation supporting a federal university, more specifically on its economic and financial performance and on the volume of its operations.

In analyzing the data and discussing the results, the null hypothesis was rejected, because GOVI had a positive influence on dependent variable values.

The logistic regression results (Table 5) showed that the governance model adopted by the third sector organization had an impact on the foundation's directions, whether perpetuating agency conflicts resulted from UFU's interference, maintaining its ineffectiveness in the search for better conditions of content production and increasing resources, or sustaining a model based on marketing time slots to outsourced programs, which caused an external dependency of a highly unstable market.

The present study has achieved several specific goals. It has created an index of governance, which can be compared to several aspects inherent to RTU's activities, including financial and economic performance and volume of operations. Other comparison metrics can be used, and the model herein created and validated to obtain the constructs and variables to be included in GOVI (questionnaire) may lack some adjustments to the specifics of the activities in any given third sector organization.

In drawing parallels between governance, on the one hand and economic and financial performance and volumes of operation, on the other hand, the results point to a close relationship of the management formats adopted in each period with the dependent variables (ROA, ROE, IPCT, NM, PHP, LHP and Empl.). This may be explained by the absence of initial concern with resources for funding, using loans from other foundations, facing a phase of continual debt, together with the search for resources through the use of third-party programs, to reaching a stage of changes in the relationships and search for resources through new service contracts.
Knowing the similarity across support foundations, a similar collection instrument may be used after the establishment of equivalent variables and constructs, as well as the use of the same dependent variables. Other dependent variables may be used to measure the influence of the governance model. In a broader sense, the questionnaire that was used, as well as its composition (constructs and variables), may be suitable to measure the level of governance of many third sector organizations, provided certain contextual adaptations be made in order to capture, with greater depth and specificity, aspects referring to the specific organizations' activities. However, it is important to consider that, to use the data collection instrument, mere inclusion of new observations will lead to the need to apply CFA - as well as all the other statistical tests - once again to assure reliability and specificity.

Performance measures different from those used in this work can be used as parameters for comparison with the GOVI (independent variable). These may include hours devoted to the activities, level of productivity, social return or any other that can be obtained by specific tools, such as the Balanced Scorecard, proposed by Kaplan and Norton (1992).

A contribution of this study is the validation of the collection instrument and the manner of obtaining GOVI. It adds to the literature, which lacks similar practices of performance measurement in the third sector. No other study has investigated how economic and financial performance and volume of operations relate to GOVI, which points out the theoretical contribution in the form of investigation of the influence of the governance model on RTU's performance.

In the process of assessing the reliability and consistency of the questionnaire, some variables have been removed from CFA. However, careful assessment of the impacts caused by their exclusion showed that the main aspects of measurement were already contained in other independent variables and in document analysis, and were therefore distributed across the three 
constructs. Thus, both the original questionnaire and the adjusted questionnaire did measure the same factors (albeit implicitly and in no prejudice in the formation of GOVI). Even so, further studies should use the complete questionnaire for replication and apply CFA, combined with other factors, to assess the need for adjustments.

This study also contributes to the discussion of agency problems in third sector organizations, in which management parties may have different interests and agency conflicts may emerge and hinder the fulfillment of the goals and purposes for which the organizations were created. The apparent dichotomy in the use of the construct independence should be observed in its use as an index of good governance practice, since it constitutes one of the greatest fears in the agent-principal relationship. The agent's independence can run counter the principal's interests, considering the relationship in the light of the capitalist interests, where the maximization of the profit to the shareholder is the desired goal. For nonprofit organizations in the third sector, the main objective is the achievement of benefits to the community, whether it be incorporated in larger or smaller groups. Thus, the managers' independence, without the interference of individual interests, may be beneficial, because it allows for making decisions that bring collective benefits. The management boards, such as the Board of Trustees, may be accountable for measuring and correcting courses of action, avoiding those that run counter the organization's purposes. The agency problems may also occur, but in a different way.

As a practical contribution, this study points to the possibility of improving techniques and management models through the use of governance precepts, which may foster professionalization in the management of third sector organizations.

This study is limited in it data cannot be generalized, because of: 1 ) the biases derived from a single case study; 2) the peculiarities inherent to a foundation that supports broadcasting of sounds and images; 3) a reduced sample of respondents; 4) and the time lapse of the sample.
However, new avenues have been opened for the development of new research or indepth studies on governance, performance and management of third sector organizations. Future research should investigate the relationship and influence of GOVI with other metrics, such as those generated by the Balanced Scorecard or social indexes calculated based on the organization's specificities. Future studies should also try to extrapolate the present findings with the results from other nonprofit organizations. This methodology may even be replicated for specific third sector segments or used in multiple case studies within the same segment.

\section{References}

Almeida, R. J. (2002). Conflitos entre acionistas majoritários, acionistas minoritários e administradores profissionais causados por importâncias assimétricas dos direcionadores de valor das empresas. Revista de Administração, 37(1), 6-18.

Arruda, G. S., Madruga, S. R., \& Freitas Jr., N. I. (2008). A governança corporativa e a teoria da agência em consonância com a controladoria. Revista de Administração da UFSM, 1(1), 71-84.

Band, D. (1992). Corporate governance: Why agency theory is not enough. European Management Journal, 10(4), 453-459.

Bardin, L. (2011). Análise de conteúdo. São Paulo: Ediçôes 70.

Bergamini, S., Jr. (2002). A crise de credibilidade corporativa. Revista do BNDES, 9(18), 33-84.

Berle, A. A. (1968). A república econômica americana. Rio de Janeiro: Forense.

Berle, A. A., \& Means, G. C. (1988). A moderna sociedade anônima e a propriedade privada (3a ed.). São Paulo: Nova Cultural.

Câmara, L. M. (2003). Apontamentos teóricos para subsídio à análise das práticas de controle 
social no âmbito dos conselhos de administração das organizaçôes sociais. Revista de Administração Mackenzie, 4(1),73-89.

Carlsson, R. (2001). Ownership and value creation: Strategic corporate governance in the new economy. New York: John Wiley \& Sons.

Carrion, R. M. (2000). Organizaçôes privadas sem fins lucrativos. Tempo Social: Revista de Sociologia da USP, 12(2), 237-235.

Carvalho, A. G. (2002). Governança corporativa no Brasil em perspectiva. Revista de Administração, 37(3), 19-32.

Coelho, S. C. T. (2000). Terceiro setor: Um estudo comparativo entre Brasil e Estados Unidos. Sáo Paulo: Senac.

Cornforth, C. (2011). Nonprofit governance research: Limitations of the focus on boards and suggestions for new directions. Nonprofit and Voluntary Sector Quarterly, 20(10), 1-20.

Correia, L. F., \& Amaral, H. F. (2008). Arcabouço teórico para os estudos de governança corporativa: Os pressupostos subjacentes à teoria da agência. Revista de Gestão USP, 15(3), 1-10.

Cruz, J. A. W., Quandt, C. O., Martins, T. S., \& Silva, W. V. (2010). Performance no terceiro setor - uma abordagem de accountability: Estudo de caso em uma organização não-governamental brasileira. Revista de Administração da UFSM, 3(1), 58-75.

Druker, P. F. (1997). Administração de organizaçōes sem fins lucrativos: Princípios e práticas (4a ed.). São Paulo: Pioneira.

Eeckloo, K., Van Herck, G., Van Hulle, C., \& Vleugels, A. (2004). From corporate governance to hospital governance. Authority, transparency and accountability of Belgian non-profit hospitals' board and management. Health Policy, 68(1), $1-15$.
Eisenhardt, K. M. (1989). Agency theory: an assessment and review. The Academy of Management Review, 14(1), 57-74.

Falconer, A. P. (1999). A promessa do terceiro setor: Um estudo sobre a construção do papel das organizaçóes sem fins lucrativos e do seu campo de gestão (Dissertação de mestrado). Faculdade de Economia, Administração e Contabilidade, Universidade de São Paulo, São Paulo, SP, Brasil.

Fama, E. F., \& Jensen, M. C. (1983). Agency problems and residual claims. Corporations and private property: a conference sponsored by the Hoover Institution. Journal of Law and Economics, 26(2), 327-349.

Fernandes, R. C. (2002). Privado, porém público: O terceiro setor na América Latina. 3a ed. Rio de Janeiro: Relume-Dumará.

Ferreira, L. C. M., Garcia, F. C., \& Vieira, A. (2010). Relações de poder e decisão: Conflitos entre médicos e administradores hospitalares. RAM-Revista de Administração Mackenzie, 11(6), Edição Especial.

Guimarães, L. S. R. (2008). Governança no terceiro setor: estudo descritivo-exploratório do comportamento de conselhos curadores de fundaçóes empresariais no Brasil (Tese de Doutorado). Faculdade de Economia, Administração e Contabilidade da Universidade de São Paulo. São Paulo, SP, Brasil.

Hair, J. F, Jr., Babin, B., Money, A. H., \& Samouel, P. (2005a). Fundamentos de métodos de pesquisa em administração. Porto Alegre: Bookman.

Hair, J. F., Jr., Anderson, R. E., Tatham, R. L., \& Black, W. C. (2005b). Análise multivariada de dados. Porto Alegre: Bookman.

Heckert, C. R., \& Silva, M. T. (2008). Qualidade de serviços nas organizaçóes do terceiro setor. Produção, 18(2), 319-330. 
Hudson, M. (1999). Administrando organizaçôes do terceiro setor: $O$ desafio de administrar sem receita. São Paulo: Makron Books.

Instituto Brasileiro de Geografia e Estatística. (2004). As fundaçóes privadas e associaçóes sem fins lucrativos no Brasil 2002. Rio de Janeiro: IBGE.

Instituto Brasileiro de Governança Corporativa. (2009). Código das melhores práticas de governança para fundaçôes e institutos empresariais. São Paulo: IBGC.

Jensen, M. C., \& Meckling, W. H. (1976). Theory of the firm: Managerial behavior, agency costs end ownership structure. Journal of Financial Economics, 3(4), 305-360.

Kaplan, R. S., \& Norton, D. P. (1992). The balanced scorecard: Measures that drive performance. Harvard Business Review, 7O(1), 71-79.

Leal, E. A, \& Famá, R. (2007, agosto). Governança nas organizaçóes do terceiro setor: Um estudo de caso. Anais do SEMEAD Seminários em Administração, São Paulo, SP, Brasil, 10. Recuperated from http://sistema. semead.com.br/10semead/sistema/resultado/ trabalhosPDF/400.pdf

Machado, C. A. P., Fo., Mizumoto, F. M., \& Zylberstajn, D. (2006). Governança e a lógica das associaçóes de interesse privado: Um estudo de caso da Associação Brasileira das Indústrias de Massas Alimentícias (ABIMA). Revista de Gestão USP, 13(4), 1-10.

Marinelli, M. (2005). Um estudo exploratório sobre o estágio da governança corporativa nas empresas brasileiras. Revista Brasileira de Gestão de Negócios, 7(19), 57-63.

Marôco, J. (2010). Análise de equaçóes estruturais: Fundamentos teóricos, software e aplicaçōes. Pêro Pinheiro: ReportNumber.

Martins, G. A. (2000). Manual para elaboração de monografias e dissertaçóes. São Paulo: Atlas.
Mason, C., Kirkbride, J., \& Bryde, D. (2007). From stakeholders to institutions: The changing face of social enterprise governance theory. Management Decision, 45(2), 284-301.

Matarazzo, D. C. (2010). Análise financeira de balanços: Abordagem gerencial. São Paulo: Atlas.

Mcgill, M. E., \& Wooten, L. M. (1975). Management in the third sector. Public Administration Review, 35(5), 444-455.

Melo, F. P., Neto, \& Froes, C. (1999). Responsabilidade social e cidadania empresarial: $A$ administração do terceiro setor. Rio de Janeiro: Qualitymark.

Mendonça, L. R.; Machado, C. A. P., Fo. (2004). Governança nas organizaçôes do terceiro setor: Considerações teóricas. Revista de Administração, 39(4), 302-308.

Mindlin, S. E. (2009). A governança de fundaçóes e institutos empresariais: Um estudo exploratório (Tese de Doutorado). Programa de Pós-Graduação em Administração, Universidade de São Paulo, São Paulo, SP, Brasil.

Monks, A. G., \& Minow, N. (2004). Corporate governance. Oxford: Blackwell.

Montaño, C. (2002). Terceiro setor e questão social: Crítica ao padrão emergente de intervenção social. São Paulo: Cortez.

Noreen, E. (1988). The economics of ethics: A new perspective on agency theory. Accounting Organizations and Society, 13(4), 359-369.

O’Neill, M. (1998). Nonprofit management education: History, current issues, and the future. In: M. O’Neill, \& K. Fletcher (Eds.), Nonprofit management education: US and world perspectives (pp. 3-12). Westport: Praeger.

Pegoraro, L. (2008). Instituições de educação superior e entidades mantenedoras: A Universidade do Contestado. Roteiro, 33(1), 25-50. 
Pimenta, S. M., \& Brasil, E. R. (2009). Gestores e competências organizacionais no terceiro setor em Itabira-MG. Gestão \& Regionalidade, 22(64), 78-89.

Pinto, A. M. G., \& Junqueira, L. A. P. (2009). Relaçóes de poder em uma rede do terceiro setor: um estudo de caso. RAP-Revista de Administração Pública, 43(5), 1091-1116.

Puyvelde, S. V., Caers, R., Du Bois, C., \& Jegers, M. (2012). The governance of nonprofit organizations: Integrating agency theory, with stakeholder and stewardship theories. Nonprofit and Voluntary Sector Quarterly, 41(3), 431-451.

Ramos, G. C. (2003). Terceiro setor: A construção de uma economia da solidariedade. Revista Gerenciais, 2, 105-111.

Rodrigues, A. L., \& Malo, M. C. (2006). Estruturas de governança e empreendedorismo coletivo: O caso dos doutores da alegria. Revista de Administração Contemporânea, 10(3), 29-50.

Ross, S. A. (1973). The economic theory of agency: The principal's problem. American Economic Association, 63(2), 134-139.

Salamon, L. (1998). A emergência do terceiro setor: Uma revolução associativa global. Revista de Administração, 33(1), 5-11.
Salamon, L. M., \& Anheier, H. K. (1992). In search of the non-profit sector II: The problem of classification. Voluntas: International Journal of Voluntary and Nonprofit Organizations, 3(3), 267-309.

Silveira, A. D. M. (2002). Governança corporativa, desempenho e valor da empresa no Brasil (Dissertação de Mestrado). Faculdade de Economia, Administração e Contabilidade da Universidade de São Paulo, São Paulo, SP, Brasil.

Silveira, D., Borba, J. A. (2010). Evidenciação contábil de fundações privadas de educação e pesquisa: Uma análise da conformidade das demonstraçôes contábeis de entidades de Santa Catarina. Revista Contabilidade Vista \& Revista, 21(1), 41-68.

Tsai, P. Y., Yamamoto, M. M. (2005). Governança corporativa: Análise comparativa entre o setor privado e o terceiro setor. Anais do Congresso USP de Iniciação Cientifica em Contabilidade, Sáo Paulo, SP, Brasil, 2. Recuperated from http://www.congressousp.fipecafi.org/web/ artigos22005/589.pdf

\section{About the authors:}

1. Lucimar Antônio Cabral de Ávila, $\mathrm{PhD}$ in Business Administration from Getulio Vargas Foundation/ EAESP. E-mail: lcavila@ufu.br

2. Carlos Osmar Bertero, PhD in Business Administration from the Cornell University.

E-mail: carlos.bertero@fgv.br 
Lucimar Antônio Cabral de Ávila / Carlos Osmar Bertero

\section{Contribution of each author:}

\section{Contribution}

1. Definition of research problem

2. Development of hypotheses or research questions (empirical studies)

3. Development of theoretical propositions (theoretical Work)

4. Theoretical foundation/ Literature review

5. Definition of methodological procedures

6. Data collection

7. Statistical analysis

8. Analysis and interpretation of data

9. Critical revision of the manuscript

10. Manuscript Writing

11. Other (please specify which)

\section{Lucimar Ávila}

\section{$\sqrt{ }$}

$\sqrt{ }$

$\sqrt{ }$

$\sqrt{ }$

$\sqrt{ }$

$\sqrt{ }$

$\sqrt{ }$

$\sqrt{ }$

$\sqrt{ }$
Carlos Bertero

$\sqrt{ }$

$\sqrt{ }$

$\sqrt{ }$

$\sqrt{ }$

$\sqrt{ }$

$\sqrt{ }$ 